\title{
TRABALHO E POLÍTICA EM SÃO BERNARDO: ARQUEOLOGIA DE UMA HEGEMONIA PRECÁRIA
}

Ruy Braga ${ }^{\mathrm{a}}$ aé professor do Departamento de Sociologia da Universidade de São Paulo (USP). São Paulo, SP, Brasil.E-mail: <ruy.braga@usp.br> Orcid: 0000-0002-8512-4306 http://dx.doi.org/10.1590/0102-133165/104

\section{Apresentação}

Em março de 2016, a convite da professora Natalia Brizuela, participei do lançamento do dossiê da revista Film Quarterly (v. 69, n. 3) dedicado ao legado do cineasta Eduardo Coutinho. O evento ocorreu no intervalo da apresentação de dois documentários de Coutinho, Boca de Lixo (1993) e Peões (2004), no prédio recém-inaugurado do Berkeley Art Museum and Pacific Film Archive (BAMPFA). A professora Brizuela pediu-me para introduzir o filme Peões ao público presente e, rapidamente, fiz alguns comentários sobre o método etnográfico "radical" de Coutinho e sua habilidade de condensar os dilemas da visão social de mundo dos subalternos em entrevistas traspassadas por um profundo sentido de dignidade humana.

Além disso, busquei contextualizar historicamente o tema de Peões, isto é, o filme que, rodado em 2002, ano da eleição de Lula da Silva, Coutinho dedicou à trajetória da classe operária fordista do $\mathrm{ABCD}$ paulista. Observei como o documentarista foi hábil em restituir a agência histórica aos próprios trabalhadores. Afinal, tendo em 
vista o sucesso de Lula da Silva e da burocracia sindical de São Bernardo, muitas vezes não nos lembramos que foi aquela classe operária semiqualificada, retratada nas telas por meio de algumas trajetórias individuais exemplares, a verdadeira protagonista do ciclo das greves de 1978, 1979 e 1980. Insisti na ideia de que os peões explicam o ativismo de Lula da Silva, mas Lula da Silva não consegue explicar o ativismo dos peões ${ }^{1}$.

Lembrei ao público que após o golpe de 1964, a ditadura civil-militar interveio nos sindicatos, perseguindo as lideranças comunistas do ABCD paulista e substituindo-as por antigos pelegos diversas vezes batidos nas eleições sindicais e usualmente alinhados aos setores conservadores da igreja católica. Paulo Vidal foi o mais bem-sucedido desses sindicalistas. Conhecido por entregar militantes de esquerda para a polícia e ameaçar quem falasse em greve, Vidal foi o predecessor de Lula da Silva na presidência do 134 Sindicato dos Metalúrgicos de São Bernardo. O "sindicalismo autêntico", como ficou conhecido esse estilo sindical, nada mais era do que uma tentativa extemporânea de negociar com as multinacionais da região pequenas concessões materiais ao estilo do business unionism estadunidense (sindicalismo de negócios), no qual a nova burocracia de São Bernardo espelhava-se.

Deparando-se com o total desinteresse das empresas em negociar com os trabalhadores, afinal, o golpe de 1964, entre outras funções, serviu para barrar as concessões materiais ao operariado, conquistadas pelas greves do período populista, e pressionados pelo aumento da mobilização das suas próprias bases, a escolha de Lula da Silva como sucessor de Paulo Vidal em 1976 marcou o momento da renovação das velhas práticas pelegas de controle da insatisfação operária pela burocracia sindical. Diante da inevitabilidade da

\footnotetext{
${ }^{1}$ Ver, entre outros, Batalha (2000) e Marson (1992).
} 
greve, Lula da Silva soube se reinventar politicamente, passando de instrumento do assistencialismo sindical à principal liderança de um movimento operário intempestivo e, até certo ponto, imprevisível.

No entanto, o documentário de Coutinho mostra uma dimensão ainda mais sutil dessa história. Na realidade, o filme soube capturar a relação dialética entre a insatisfação, os desejos e as iniciativas políticas dos peões, verdadeiros sujeitos de sua própria história, e a tentativa de controlar esta agência empreendida por Lula da Silva. Recorrendo a outros filmes da época, em especial, o já clássico Linha de Montagem (1982) de Renato Tapajós, Coutinho revelou por meio de detalhes - o choro, a ansiedade, a chantagem emocional e o pedido do voto de confiança -, o nascimento de uma liderança política ainda desconfiada de sua própria força.

Ao mesmo tempo, o cineasta mostrou como nesses instantes de fragilidade de Lula da Silva, os dilemas dos próprios operários em seu "fazer-se" história condensavam-se e encontravam um sentido mais ou menos consciente. Trata-se do nascimento de uma forma de hegemonia precária capaz de amalgamar o consentimento popular em torno de um projeto burocrático de poder, ainda que à custa de sua autodeterminação política, isto é, como grupo social capaz de definir autonomamente seus próprios objetivos (Oliveira, Braga e Rizek, 2010). Assim, forjou-se a relação entre os peões e a burocracia sindical de São Bernardo, ao mesmo tempo, limitando e potencializando a pulsão plebeia por trás do ciclo grevista, além de conduzi-la na direção da negociação com o regime autoritário e com as empresas da região. Sabemos que daí surgiu um líder cuja legitimidade deriva do controle da insatisfação popular por meio de negociações que lentamente garantem pequenas concessões aos trabalhadores. Uma força social reformista a afiançar o armistício entre a autonomia dos subalternos e a presunção dos dominantes. 


\section{Trabalho e política: o regime fabril despótico de São Bernardo}

Obviamente, essa história remonta à integração do operariado fordista do cinturão industrial de São Paulo ao regime fabril despótico consolidado pela regulação autoritária durante o final dos anos 1960 e início dos anos 1970, período conhecido como "milagre brasileiro" devido às altas taxas de crescimento econômico. O objetivo deste artigo consiste em revisitar etnografias do trabalho operário e estudos de caso que se concentraram na análise da formação da inquietação operária na região do ABCD paulista a fim revelar os momentos-chave que explicam a eclosão daquele ciclo grevista ocorrido há exatos quarenta anos atrás. Além disso, pretendemos identificar o surgimento do embrião daquela relação social hegemônica que aproximadamente três décadas mais tarde, iria assumir, por meio do governo federal, a direção do modelo de desenvolvimento 136 brasileiro, florescendo como a base do modo de regulação lulista dos conflitos sociais.

Em nossa opinião, essa relação social começou a se insinuar durante a primeira metade dos anos 1970 através das iniciativas da burocracia sindical de São Bernardo em estabelecer negociações por melhores salários e condições de trabalho nas fábricas. Concentrando-se em empresas automobilísticas de São Bernardo - uma delas, a mesma pesquisada por Rodrigues cerca de uma década antes -, Humphrey refutou a ideia de que o precariado metalúrgico seria formado majoritariamente por operários jovens e sem tradição de trabalho industrial ${ }^{2}$. Nas duas fábricas automobilísticas

\footnotetext{
2 Empregamos o conceito de "precariado" para designar o proletariado precarizado, isto é, aquela fração da classe trabalhadora desqualificada ou semiqualificada que é submetida a altas taxas de rotatividade do trabalho. Devemos acrescentar também os jovens trabalhadores à procura do primeiro emprego, indivíduos que estão na informalidade e desejam alcançar o emprego formal, além de trabalhadores subremunerados (no caso brasileiro, aqueles que recebem até um salário mínimo e meio) e inseridos em condições degradantes de trabalho. Uma população que, no
} 
estudadas, cerca de $61 \%$ dos operários eram classificados pela companhia como operários não qualificados (20\%) ou semiqualificados $(41 \%)$, a maioria já contando com algum grau de experiência urbana e industrial. A despeito dessa proporção ser mais elevada do que as encontradas nos setores tradicionais, esse percentual não diferenciava a indústria automobilística dos demais ramos metalúrgicos.

A abundante oferta de força de trabalho não qualificada no pós-guerra, somada aos progressos da automação e do controle gerencial, estimulou as montadoras a recrutar no mercado externo de trabalho. Na medida em que a experiência operária era menos importante para a elevação da produtividade do trabalho, o interesse das empresas em estabilizar os trabalhadores declinou. Como bem demonstrou Humphrey, a política da rotatividade da força de trabalho ajudava a estruturar um sistema industrial que não apenas servia para garantir a obtenção da disciplina operária devido ao medo do desemprego, como também favorecia o aumento de produtividade.

A subordinação da folha salarial ao departamento financeiro das empresas também permite perceber por que a progressão funcional levava à demissão. Ao progredirem na carreira, os operários semiqualificados que alcançavam as posições mais altas eram demitidos e substituídos por jovens não qualificados, que recomeçavam o ciclo. Este supunha a existência de uma complexa hierarquia salarial que anunciava aumentos atribuídos em parcelas e por períodos conforme o parecer das chefias. O operário buscava, então, trabalhar disciplinadamente para ascender a uma faixa salarial mais elevada. Quando o operário por fim conseguia

Brasil, aumentou muito desde a década de 1990. Não nos esqueçamos que, mesmo com o avanço da formalização do emprego entre os anos de 2003 e 2015, as taxas de rotatividade, de flexibilização e de terceirização e o número de acidentes de trabalho no país subiram no mesmo período. Em suma, o precariado é formado pelo setor da classe trabalhadora pressionado pelo aumento da exploração econômica e pela ameaça da exclusão social (Braga, 2012). 
alcançar essa faixa, era demitido e substituído por outro, que recomeçava com um impulso renovado o mesmo ciclo desde as faixas salariais mais baixas.

Assim, não é difícil compreender o desinteresse da indústria em negociar com os sindicatos. Para Humphrey (1983), esse sistema industrial conduziu os operários da indústria automobilística na direção dos mesmos interesses do restante da classe trabalhadora brasileira. Além disso, após 1964, o precariado metalúrgico - diferentemente dos operários qualificados que ainda percebiam certos reajustes salariais - sofreu mais agudamente com a carestia. Durante o período do "milagre econômico" (1968-1975), a inquietação operária motivada pela deterioração salarial, assim como pela intensificação da produtividade do trabalho, fomentou formas passivas de resistência entre as fileiras operárias:

Cada um tem uma mentalidade. Tem pessoas que zela pela sua máquina, cuida. Otras vê a máquina cum raiva. Qué distruí. Cabá cum aquilo. Isso acontece dimais numa seção. E se alguém fala cum eles... ele fala: Num é meu não, rapaiz... Deixa isso cabá. [...] Quando recebe uma órdi... a maioria das pessoa vai quétinho fazê aquilo mais pur dentru ele tá remuendo (Rainho, 1980, p. 65).

Ou ainda:

Então, eu cunversei cum ele e falei: escuta u senhor não passa pelo nosso problema. U senhor não tem que enfrentá aquela fila de torneira. U senhor num tem que pegá u ônibus. U senhor tem u seu carro. U senhor não suja as mãos. U senhor é mestre. U senhor lida cum papel. U senhor teria que passar pelo nosso problema pra entendê u qui é isso. Mas ele fala não, que a norma da firma é essa e que nóis temo que... vivê assim. Então, a gente combinô, sabe? Isso foi uma reação da turma... ele qué nos proibi saí 
cinco e vinte e cinco da seção, falamo: Não, nóis temo que saí todo mundo junto cinco e vinte e cinco, até ele desisti. Ele vai ameaçá, dá carta de advertência... fazê u diabo. Mas a gente num deve desisti, sabe? Cinco e vinte e cinco sai todo mundo junto. E, nóis tamo saindo. E ele fica doido, sabe? Então, a gente sai cinco e vinte cinco, depois volta pra seção pra marcá u cartão (Rainho, 1980, p. 77).

Isso sem mencionar o descontentamento com o trabalho noturno e com o interminável número de horas extras que, tendo em vista a pressão das empresas, o operariado como um todo era obrigado a aceitar. Na realidade, os longos períodos de horas extras em um setor que normalmente exige acentuado esforço físico, ocasionando fadiga intensa e acidentes de trabalho, consolidaram-se como uma prática comum na indústria automobilística brasileira:

Esse problema de extra... isso aí é um troço antigo... ninguém conserta. A firma interessa e às veiz u peão exige... inclusive nu meu setor eles tão na maior briga lá. Uns elemento querem emprestado pra outro setor pra fazê hora extra... esse otro setor u pessoal num fazia hora extra... num querem fazê hora extra, reivindicando melhó salário. Então eles deixam de pagá... u salário... um pouquinho mais pr'aqueles que eles mantém aquilo lá... e eles às veiz vão pagá o dobro mais... elementos que ali em baixo tá ganhando quatro... eles vão pagá oito pru peão í fazê aquela hora extra. E u peão vai. Vai matando. Porque ele ganha um pouquinho mais. Aquilo pra ele fazendo hora extra é um negócio. Sem sabê que ele tá prejudicando u companheiro e ele... aí então quando foi agora, esses dias... é... devido u pessoal tê entrado cum u processo de pedido de integração de hora extra, férias, décimo tercero, essas coisa. [...] Ocê tem que sabê que si ocê num vivê cum oito hora, ocê num vive nem cum vinte. Depois ocê tem que sabê que se ocê 
fô fazê hora extra só a firma é que tem a ganhá: ocê perde a saúde, energia, prejudica aquele seu companheiro, tira o emprego de dois ou treis que tá lá fora precisando de trabaiá (Rainho, 1980, p. 101).

Facilmente substituído e percebendo salários menores, o precariado metalúrgico experimentava sérias limitações para poder resistir à imposição das longas jornadas e ao aumento dos ritmos do trabalho. Na vívida descrição de Rainho, podemos compreender os expedientes utilizados por esses trabalhadores para aumentar a produção, assim como apreender a multiplicidade de fontes de pressão pela intensificação dos ritmos de trabalho que os submetiam:

Mas, como apesar do estado permanente de cansaço os operários não podem deixar de produzir, fazem, então, o que chamam de "apelar" para conseguirem "vencer" o dia de trabalho. [...] Durante um certo tempo, mesmo o corpo não querendo, abstraem-se de tudo e voltam-se inteira e obcecadamente para o trabalho que, realizado com afinco e rapidez, lhes possibilita "esquentar o sangue" e ir até o final do expediente. Mas tendo acostumado o corpo ao ritmo, ele não pode ser esfriado. No entanto, invariavelmente, isso acontece com as interrupções para refeições. É então, na oportunidade, que recorrem à bebida como estimulante, em bares existentes nas proximidades das fábricas... [...] Pode também ser atribuído [o ritmo intenso de trabalho] a outros fatores, tais como: a) competição e rivalidade entre as turmas, que "já faz parte da personalidade das empresas", embora não seja assim percebida pelos próprios operários; b) pessoas em experiência que, no afã de serem aprovadas para admissão definitiva, "dão tudo o que têm"; c) outros, desejosos de obter aumento ou promoção, trabalham intensamente para mostrar aos chefes que são "bons"; d) os que não possuindo "vícios" não dosam suas energias e, 
finalmente, e) o receio de serem demitidos por não dar produção como os demais (Rainho, 1980, pp. 244-245).

Os efeitos do aumento do esforço físico eram visíveis não apenas no permanente estado de esgotamento do operário, mas, sobretudo, no aumento da produção. Entre 1970 e 1978, por exemplo, a produção na empresa revisitada por Humphrey havia dobrado, sem qualquer modernização saliente da base técnica. Não é de espantar que, a certa altura, a gerência tivesse simplesmente abandonado a cronometragem das tarefas, passando a exigir das diferentes seções metas arbitrárias: "Antes a gente tinha cronometragem. Aí estava certo. Mas agora já não. [...] Se tem dez pessoas fazendo um serviço, eles já estão pensando que é demais e que devem tirar mais dois. Às vezes não dá. Todo mundo sai nervoso daqui" (Humphrey, 1983, p. 90). Evidentemente, os problemas relacionados com as condições de saúde e de segurança dos trabalhadores aumentavam. Tendo em vista as características gerais desse sistema industrial, o que a indústria automobilística deveria fazer para atrair novos operários, renovar os ritmos e garantir a elevação da produtividade no setor? A solução inspirou-se no próprio Ford, ou seja, nos chamados "altos salários".

E o ciclo se completa: quando o precariado metalúrgico não conseguia mais acompanhar o ritmo e "dar a produção", seja por conta de fadiga, acidente ou adoecimento, era facilmente substituído por uma nova onda de jovens trabalhadores atraídos pelos altos salários praticados no setor. Além disso, produto da política de rotatividade do trabalho, as maciças flutuações do emprego no setor atingiam predominantemente o jovem precariado metalúrgico. A intensa rotação da força de trabalho, além de servir como meio de disciplinarização dos trabalhadores, correspondia à estratégia das montadoras de descarregar sobre o precariado o ônus das flutuações cíclicas das vendas de veículos, 
garantindo o aumento das margens de lucro: caso houvesse queda da demanda, os custos relativos ao pessoal deveriam ser adequados ao montante dessa queda e o volume do emprego ficava atrelado à flutuação das vendas.

Se fora da empresa os trabalhadores enfrentavam a ditadura militar, dentro das fábricas encontravam-se submetidos à autocracia dos departamentos financeiros: precariedade do emprego, instabilidade dos salários, condições inadequadas de segurança, cadências produtivas "infernais", arbitrariedade gerencial... Um ex-operário da Ford sintetizou da seguinte maneira os efeitos da combinação entre o controle e a rotatividade do operariado de São Bernardo:

Na maioria das vezes o peão, antes de ser admitido, pensa que vai trabalhar num lugar agradável, limpo, que lhe proporcionará bem-estar, segurança e bom relacionamento. Pode pensar que vai realizar aí sua vida como profissional 142 e pessoa humana. Logo, porém, vem a realidade. Tudo isso apenas encobre algo que lembra um campo de concentração. [...] Tudo dentro da fábrica está organizado para tirar o máximo do operário às custas de um desgaste físico insuportável, poluição, barulho e ritmo incansável de trabalho que deixa a pessoa humana despossuída de todas as reservas físicas, mentais e morais. [...] Quando o físico e a mente estão esgotados; quando o operário já adquiriu o suficiente número de doenças industriais incuráveis; quando vai ficando só o bagaço, então vem a substituição por um operário novo que entregará suas melhores energias que ficarão cristalizadas nos carros bonitos, produtos de seu suor, que percorrem e engarrafam as ruas das cidades, num ritmo louco de produção e consumismo muitas vezes inútil. [...] Existe a divisão artificial entre especializados e não especializados, diferenças de categorias e em cada categoria escalas, todas divisões, A.B.C.D., artificiais, com pequenas diferenças de salários, a fim de promover a concorrência 
entre os próprios operários e criar a ilusão de uma luta individual para subir de escalão; o que age contra o espírito coletivo de luta, e cria a disputa para aumentar e melhorar a produção (Brito, 1989, pp. 29-30).

Percebendo a fragilidade do sindicato em negociar salários e melhores condições de trabalho, a situação encontrada por Humphrey em 1975 pode ser descrita como de relativa inatividade. Mesmo assim, o autor reconheceu nos protestos "espontâneos" por melhores salários, liderados pelos operários qualificados das montadoras em 1973 e 1974, consistentes indícios da existência de focos de resistência operária. Combinando repressão com aumentos diferenciais de salários, a reação das empresas foi suficiente para controlar a situação, restabelecendo a "normalidade" do processo de trabalho. No entanto, logo após o fim das paralisações, o precariado metalúrgico experimentou um acentuado aumento da carga de trabalho.

Temendo a demissão, os trabalhadores submeteram-se aos ritmos impostos pelas gerências. Apesar disso, os protestos de 1973 e 1974 demonstraram a existência de uma inquietação na base suficientemente forte para alimentar a retomada das reivindicações no setor. Humphrey chega mesmo a comparar as respostas ao questionário de Rodrigues relativas às atitudes sindicais com outras obtidas a partir da tabulação de seu próprio questionário. Argumenta, então, que seus dados, apesar de não serem suficientes para afirmar que as fábricas de automóveis no Brasil estariam povoadas de operários com consciência de classe, permitiam ao menos afastar o ceticismo em relação à auto-organização sindical.

\section{Da consciência contingente à consciência necessária}

Entendimento próximo já podia ser observado na pesquisa de campo realizada por Celso Frederico no final dos 
anos $1960^{3}$. Entrevistando operários de uma metalúrgica de Santo André, Frederico soube anunciar pioneiramente a transformação do conhecimento do objeto rumo à análise do regime fabril. Mobilizando um amplo cabedal de autores marxistas clássicos e contemporâneos - de Lukács a Lenin, passando por Rosa Luxemburgo e Ernest Mandel -, o autor construiu uma interpretação relativamente inédita entre nós a respeito da consciência operária, cujo eixo gravitava em torno da teoria lukacsiana da reificaçã $o^{4}$. Assim, buscou compreender a consciência do grupo operário como uma processualidade na qual coexistiam, contraditoriamente, tanto a "falsa consciência" - isto é, as formas contingentes, fragmentadas e imediatas da consciência psicológica dos operários subsumidos ao processo de coisificação das relações capitalistas de produção - quanto vestígios de "consciência necessária”, ou seja, a consciência capaz de reconhecer no operariado um sujeito político.

144 Amparado por suas entrevistas, ele concluiu que os operários mais qualificados e experientes atuavam como o grupo mais avançado e reivindicativo dentro da fábrica e que os ajudantes - pelo fato de serem jovens, solteiros, não qualificados ou semiqualificados - representavam uma massa politicamente inorgânica. Ainda assim, Frederico identificou formas elementares da consciência de classe que, em determinadas condições históricas, poderiam evoluir para formas politicamente ativas. Por constituírem o setor mais dominado e explorado do grupo operário, o precariado metalúrgico, mesmo interpretando sua situação em termos mais vantajosos do que a do precariado rural, percebia claramente as dificuldades para progredir no interior da empresa. Por um lado, se a expectativa de progresso ocupacional reforçava certo conformismo, por outro, essa esperança

\footnotetext{
${ }^{3}$ Ver Frederico (1978).

4 Evidentemente, não ignoramos o trabalho pioneiro de Michael Löwy sobre História e consciência de classe. Ver Löwy (1962) e Löwy e Chucid (1962).
} 
chocava-se cotidianamente com o medo da demissão, a realidade da carestia e a intensificação do trabalho. Em certos momentos, essa tensão latente conseguia erodir as barreiras do conformismo, vocalizando uma inquietação capaz de fustigar até mesmo o sindicato:

Pedro: "O sindicato tinha mais força antigamente. Agora ele caiu muito com a mudança de governo. O Castelo Branco entrou aí e acabou com tudo. O sindicato não pega mais força. Antes do Castelo os sindicatos tinham força, depois mudou. O Castelo disse que sindicato não resolvia nada, era tudo com ele que se resolvia. $\mathrm{O}$ sindicato perdeu a força que tinha. Naquela época, se o cara queria aumento, arrumava cinco pessoas, ia lá e resolvia. Até greve podia fazer que o sindicato garantia. Agora aumento é só de ano em ano por lei, e se os trabalhadores fazem greve o patrão chama a cavalaria sobre a gente. O Presidente da República ajudava o sindicato, qualquer coisa o sindicato falava com o presidente e conseguia. Agora o sindicato tem uma desculpa: diz que os trabalhadores caíram muito, que eles estão com medo”. Ciro: "O sindicato não vale mais nada. Antigamente ele tinha mais força, mandava parar, parava. Depois que entrou o governo militar, eles cassaram e prenderam os dirigentes sindicais. Hoje é tudo mandado pelo governo. Antigamente tinha greve, eles tinham força para fazer greve e pedir aumento. Eles tinham força porque o governo apoiava eles também. Não é que apoiava, é que tinha liberdade de fazer. Com esse governo acabou. Os operários não fazem mais greve porque não podem. Agora não pode nem falar, o governo prende" (Frederico, 1978, pp. 62-63).

Nem por isso o conformismo instalou entre os metalúrgicos. Incerta, a inquietação operária assumiu a forma da contenção da produção. Objetivando pressionar a empresa por aumentos salariais, a conhecida técnica de diminuir o 
ritmo de trabalho surgiu como um estratagema dos grupos profissionais para pressionar a gerência. Em certa medida, a limitação produtiva substituiu o recurso à greve. Tendo em vista a fragilidade do movimento sindical, os operários se viam cada dia mais dependentes da utilização de enfrentamentos "espontâneos" no chão de fábrica para defender seus salários. Nesse sentido, a contenção identificada por Celso Frederico entre os anos de 1970 e 1971 prefigurou a resistência operária em 1978:

Orlando: "O engenheiro chegou pedindo aumento de produção, mas não falou em aumento de salário. No primeiro dia nós demos a produção que ele queria e pedimos aumento. Ele negou. Todo mundo amarrou a produção! Foi impressionante! Não foi um nem dois, foi todo mundo. Aí entramos em entendimento e deram aumento. Antes disso houve ameaças de despedir os operários, mas como era todo mundo que amarrava eles não podiam mandar todos embora" (Frederico, 1978, p. 91).

De fato, se a condição operária é capaz de promover uma espécie de consciência prática crítica do sistema de relações industriais fordista, não devemos negligenciar o papel que a crítica prática, isto é, aquelas “orientações políticas assumidas pelas organizações sindicais e partidárias”, cumpriu no amadurecimento da experiência operária. Herdados do período populista e intensamente perseguidos pelos militares, os agrupamentos políticos ressurgiram nas oposições sindicais. Estas empenharam-se em organizar "comitês de fábrica", passando a disputar com o aparato burocrático a influência sobre o operariado. Se durante o "milagre" econômico a influência das oposições sindicais nas fábricas tendeu a declinar tendo em vista a combinação da repressão militar com a delação dos militantes pelos “pelegos sindicais”, já em meados dos anos 1970 a revivificação do ativismo na base referendou o trabalho das oposições. 
O golpe de 1964 redefiniu o peso da classe trabalhadora no interior do modelo de desenvolvimento. As altas taxas de crescimento econômico entre 1968 e 1975, somadas à repressão ao operariado, deslocaram as tensões classistas para o interior das fábricas, ocultando a deterioração de salários e de condições de trabalho por meio de uma mobilidade ascendente acessível a uma minoria. De fato, imediatamente após o golpe, a destruição do sindicalismo populista e o recuo dos sindicatos para uma função de mero apoio assistencial erodiram o poder de barganha da classe operária. Além disso, a implantação do Fundo de Garantia do Tempo de Serviço (FGTS), ao facilitar as demissões, estimulou a concorrência entre os próprios trabalhadores, pressionando os salários para baixo. Para completar esse quadro, os operários temiam que uma eventual participação no sindicato redundasse em prisões e inquéritos na Justiça Militar.

Além disso, como bem observou Frederico, a passagem da barganha salarial coletiva para a barganha individual serviu para aumentar ainda mais a fratura no interior da própria classe. O jovem precariado metalúrgico viu a distância entre seus salários e os dos grupos profissionais aumentar. Enquanto estes procuravam se defender do arrocho por meios "corporativistas", o precariado viu-se abandonado à própria sorte.

\section{Da burocracia sindical à vanguarda metalúrgica}

Em meados da década de 1970, esse grupo operário insatisfeito com a rotatividade, a intensidade do trabalho e o aumento da carestia encontrou-se com uma burocracia sindical herdeira do colapso do populismo em busca de sua própria identidade: a pauta reivindicativa do Sindicato dos Metalúrgicos de São Bernardo acantonava demandas que iam da liberalização do controle sobre os sindicatos à negociação coletiva livre com o restabelecimento do direito de greve. Contudo, a mesma pauta nada dizia sobre o fim da 
unicidade sindical. Outro importante ponto da reivindicação metalúrgica era a demanda por comissões de fábricas mistas no interior das empresas, com garantias de estabilidade para os delegados sindicais.

Carente de canais de comunicação com o governo e com as empresas, pressionada pelas condições de vida das bases e pela presença da oposição sindical, essa burocracia liderada por um conhecido "pelego", Paulo Vidal, foi apurando sua prática "apolítica": facilitar a filiação dos trabalhadores ao sindicato, aperfeiçoar o serviço de assistência médica e social e construir uma nova sede, além de manter permanentemente o foco sobre o poder de compra dos salários. E no momento em que a ditadura militar começava a emitir os primeiros sinais de fadiga, essa burocracia mostrou-se permeável à inquietação operária, especialmente em relação à insatisfação com as horas extras e com a rotatividade do trabalho. Em grande medida, essa sensibilidade 148 decorria do fato de que uma parte importante dessa burocracia se originara no setor automobilístico ${ }^{5}$.

As demandas dos sindicalistas de São Bernardo mostraram-se afinadas com a limitação do controle do Estado sobre os sindicatos e com o restabelecimento dos direitos democráticos aos trabalhadores. Foram as principais características do fordismo periférico, tais como o despotismo fabril, a alta rotatividade e as longas jornadas, somadas à repressão política e ao arrocho salarial, que alimentaram a inquietação operária, conduzindo a burocracia sindical ao confronto com as empresas e os governos ${ }^{6}$. Buscando soluções para os problemas imediatos do operariado metalúrgico, essa burocracia - particularmente após a entronização de Lula

\footnotetext{
5 Por burocracia sindical entendemos um fenômeno social, a um só tempo, econômico, institucional e político, apoiado sobre o desenvolvimento de uma camada social que se apropria de funções organizativas previamente exercidas pelos próprios trabalhadores, ou seja, a burocracia operária. Ver Mandel (1992).

${ }^{6}$ Sobre o conceito de despotismo fabril, ver Burawoy (1985).
} 
da Silva na presidência do sindicato, em 1975 - inspirou a mobilização de outros grupos de trabalhadores pelo direito de greve, por conquistas salariais, por formas de negociação coletiva e pela redemocratização do país.

A recessão econômica experimentada pelo capitalismo avançado, entre 1973 e 1979, atingiu a economia brasileira, deteriorando a capacidade do país de pagar encargos da dívida externa. Assim, em meados na década de 1970, o regime começa a emitir os primeiros sinais de distensão política, com a escolha de Ernesto Geisel para a Presidência da República. Além disso, a denúncia de manipulação dos índices inflacionários de 1973 a 1975 somou-se à insatisfação com a carestia, incentivando a campanha pela reposição salarial de 1977 e a eclosão do grande ciclo grevista do ABCD paulista. A inquietação que catalisou esse ciclo grevista apoiou-se na convergência de um pequeno grupo qualificado e relativamente estável de trabalhadores com o jovem precariado metalúrgico, concentrado e permeável à ação dos agrupamentos políticos clandestinos nas fábricas.

Em termos sumários, tendo em vista, sobretudo, o incremento do número de sindicalizados e o militantismo demonstrado por seus novos quadros, a burocracia sindical de São Bernardo passou por uma revivificação que culminou, em 1975, na eleição de Lula da Silva para a presidência da entidade. $\mathrm{O}$ sindicato passou então a ser reconhecido como um interlocutor confiável por algumas empresas-chave do setor, dentre as quais a própria Ford. Mas a grande reviravolta na conjuntura adveio do encontro da crise econômica com um renovado criticismo da sociedade civil. Cresce, então, a oposição nas ruas - protestos estudantis - e na imprensa - por meio de periódicos alternativos etc. -, além de vitórias eleitorais significativas da oposição parlamentar. Um esboço de distensão do regime começou a ser ventilado por lideranças militares e as direções sindicais se sentiram mais livres para retomar uma atividade militante 
mais combativa. Em São Bernardo, a burocracia sindical decidiu lançar uma campanha salarial apoiada em um notável esforço de panfletagem e em assembleias com ampla participação dos trabalhadores.

\section{Da rebeldia das bases ao ciclo das greves}

Em 1977, a euforia com o "milagre econômico" já havia passado. Ao contrário, atingidos pela carestia e submetidos a duras condições de trabalho, os metalúrgicos experimentavam o aumento da desigualdade promovido pelo modelo de desenvolvimento: "Uns dizem que o Brasil tá melhorando muito. Outros dizem: Olha, é cumo uma abobra podre... [...] O Brasil tá melhorando para os ricos e piorando para os pobres. [...] Os aumentos do salário não resolvem a situação" (citado em Rainho, 1980, pp. 156-157). Além disso, a experiência com as eleições parlamentares de 1974, quando o oposicionista Movimento Democrático 150 Brasileiro (MDB) inesperadamente venceu a Aliança Renovadora Nacional (Arena) por ampla margem de votos, deixou claro que mesmo uma vitória da oposição parlamentar não seria suficiente para alterar a situação dos operários. O desinteresse dos metalúrgicos pela eleição de 1978 mostrou que eles se distanciavam de uma solução parlamentar para os impasses do regime:

As eleições, pur exemplo, são daí a quinze dias, mais u pessoal num tem nem comentado. Mesmo sendo pessoal de fábrica, é a primeira eleição qui eu vejo uma frieza total da classe. [...] Ninguém fala que vai votá nesse ou naquele. Cumo política, eu nunca vi uma pulítica tão fria desse jeito. Parece qui u operário tá dando u maior desprezo em pulítica. [...] Na última eleição eu votei no Quércia e MDB e esse ano vou votá novamente no MDB que vai entortar a Arena. Agora pra mim nem um dos dois partidos fazem diferença (citado em Rainho, 1980, pp. 155-156). 
A essa decepção somou-se a indignação com a manipulação dos índices inflacionários. Liderada pelo sindicato de São Bernardo, a campanha salarial de 1977 enfatizou a necessidade de recuperar tais perdas. Como resultado do esforço de mobilização do sindicato, as assembleias operárias tornaram-se muito concorridas, levando a direção sindical a usar campos de futebol para abrigar a imensa quantidade de trabalhadores que queria participar das reuniões. A agitação operária, naturalmente, repercutiu no interior das fábricas, onde os operários usavam qualquer horário disponível para debater a campanha. Comissões de fábrica foram criadas nas empresas em que não existiam e as comissões já existentes foram renovadas pela mobilização das bases.

Diante desse quadro, Lula da Silva declarou em seu discurso de posse à frente do sindicato, em 21 de abril de 1978, que a paciência em negociar com as empresas e com o governo já havia se esgotado:

Depois de sete meses, cheguei lamentavelmente à conclusão de que a classe empresarial não quer negociar com seus trabalhadores, mas tirar toda a sua força física, até a última gota de suor. Por isso está na hora de deixar o diálogo de lado e partir para a exigência. Sem medo de nada (Lula da Silva apud Antunes, 1992, p. 18).

A campanha salarial de 1978 representou para a burocracia sindical uma oportunidade ímpar, não apenas de consolidar o nível de mobilização conquistado no ano anterior, mas também de atrair os operários mais ativos na base.

A campanha enfatizou a inutilidade da negociação com o governo, afirmando que para reaver as perdas salariais os metalúrgicos deviam paralisar a produção: "Foi uma campanha de praticamente cinco meses, mostrando ao operário que ele só recuperaria esse dinheiro se partisse pro pau. E quando nós trabalhadores usamos esse linguajar 
de partir pro pau, não é brigar não, é simplesmente parar as máquinas" (Lula da Silva apud Humphrey, 1983, p. 156). As reivindicações espalharam-se de forma rápida pelas empresas, evidenciando um avançado processo de auto-organização das bases. Apesar da disposição demonstrada pela burocracia sindical de São Bernardo, de estreitar os vínculos com o jovem precariado metalúrgico, a eclosão de um forte movimento grevista enraizado no chão de fábrica apanhou de surpresa até mesmo a diretoria recém-eleita. Nesse momento, o papel do sindicato limitou-se a intermediar os conflitos entre os operários grevistas e as empresas. Nas palavras de Lula da Silva:

A ação da direção sindical foi mais no sentido de representação do movimento grevista nas fábricas, quando solicitada pelos trabalhadores (e em alguns casos pelo próprio patronato, com o objetivo de buscar canais de negociação). No momento inicial, quando da eclosão das primeiras greves, o Sindicato atuou inclusive mais como intermediação entre o operariado e a direção fabril (Lula da Silva apud Antunes, 1992, p. 34).

No entanto, isso não quer dizer que as primeiras paralisações fossem de todo inesperadas. Dando mostras de sagacidade política, o sindicato já havia integrado na chapa de 1978 a parte mais ativa das jovens lideranças surgidas na região. Nesse momento, também a burocracia sindical amadureceu politicamente. Refletindo alguns meses antes do início das greves de 1978 sobre os limites do modelo de desenvolvimento, Lula da Silva afirmou:

\footnotetext{
"Mas vocês não podem parar as fábricas." Não pode em termos. Vamos dar mais um tempo que vamos ver se podemos ou não podemos. Não vejo outra forma, pô. Conversar com patrão? Já conversamos. Conversar com
} 
autoridade? Já conversamos. Ninguém tá preocupado com o trabalhador... (apud Humphrey, 1983, p. 157).

Assim, não causa espanto que uma paralisação em maio na Saab-Scania tenha rapidamente se espalhado pelas plantas da Mercedes-Benz, Ford, Volkswagen e Chrysler, envolvendo 45 mil grevistas nas primeiras semanas. A greve da Scania revelou, igualmente, outra característica do ciclo grevista: a convergência entre os operários profissionais e o jovem precariado metalúrgico. A greve iniciou-se pela ferramentaria, onde os operários apresentavam mais familiaridade com a ação sindical, conquistando rapidamente a adesão dos demais setores. Por um lado, a tradição sindical dos profissionais assegurou o início da greve, por outro, a adesão da massa precarizada garantiu seu sucesso. Ao contrário das paralisações de 1973 e 1974, limitadas à ferramentaria, a greve de 1978 apoiou-se em ambos os grupos:

A ferramentaria já estava garantida. E as outras seções? Falar para todo mundo não era bom negócio, porque ia ter alguém que ia furar o bloqueio e falar para os mestres. Mas também eles tinham que saber antes de parar. Então, pensamos nos ônibus da saída, mas não da entrada, do dia 12. Com os que sabiam, combinamos: vamos fazer um tipo de sanfona. Vamos conversar só com as pessoas de confiança de todas as seções. Esse trabalho foi feito dia 10 de meio-dia em diante e dia 11. Não foi feito mais que isso... No dia 12 a gente conversou nos ônibus que a ferramentaria ia parar e que era importante que as outras seções acompanhassem. [...] Quando chegou na sexta-feira, dia 12 de manhã, o esquema da ferramentaria estava pronto. $O$ pessoal da noite, poucos sabiam. Esse pessoal saía e já deixava o do dia trabalhando. E aquele pessoal ia saindo e ninguém que entrava começava a trabalhar... a ferramentaria não ligou as máquinas. Nas outras seções no pavilhão A ninguém ligou 
as máquinas. Só umas 3 ou 4 seções ligaram uma ou outra máquina. Eu sei que a ferramentaria parou e o pessoal de outras seções viam que ela estava parada. Aí foi indo, parou a fábrica toda (Menezes apud Antunes, 1992, p. 22).

Enraizando-se no chão de fábrica por meio do crescimento dos associados e apoiado em uma pequena, porém sólida, base de ativistas formada por operários profissionais espalhados pelas principais empresas da região, o sindicato de São Bernardo aproximou-se do jovem precariado metalúrgico a fim de fortalecer a campanha salarial. Por um lado, se as paralisações ocorridas em 1973 e 1974 haviam evidenciado que os ferramenteiros sozinhos não seriam capazes de prevalecer sobre as gerências, por outro, a convergência destes com a massa precarizada mostrou-se alvissareira. Demonstrando um considerável poder de resistência à pressão patronal, os "peões", a exemplo do que havia acontecido durante o ciclo 154 grevista de 1968, mas em uma escala muito maior, criaram e revivificaram comissões de fábrica que se transformaram nos principais meios de mobilização do movimento. Por sua vez, a burocracia sindical de São Bernardo concluiu, pressionada pelo descontentamento operário na base e pela ameaça da intervenção do Ministério do Trabalho em sua cúpula, que modificações na estrutura sindical não poderiam ser alcançadas sem o confronto aberto com a ditadura.

Surpreendidas pelo movimento, as gerências imediatamente pressionaram os trabalhadores a voltar ao trabalho antes de acenar com qualquer negociação, ameaçando demitir os grevistas e chamar a polícia. No entanto, diante da resiliência operária, muitas empresas - caso da própria Ford, um dos bastiões do sindicato - foram obrigadas a abrir negociações ainda com as máquinas paradas. Sem a necessidade de recorrer ao piquete, a tática de "picar o cartão" e "cruzar os braços", muito utilizada a partir de 1978 em São Bernardo, dependia basicamente da coordenação política 
entre os operários profissionais e o precariado metalúrgico. Essa tática foi aplicada na Volkswagen, uma fábrica conhecida por sua resistência ao sindicato, e o resultado foi a abertura de negociação com as máquinas ainda paradas.

Nesse momento, a burocracia sindical de São Bernardo apoiou as reivindicações das bases, ao mesmo tempo que se esforçava para construir uma imagem confiável perante as empresas. Liderada por Paulo Vidal, a burocracia sindical de São Bernardo atravessou a retomada da atividade política nas bases operárias apoiada na "autenticidade sindical”, noção com a qual travara contato durante os cursos preparados pelo Ministério do Trabalho. O desafio estava exatamente em coadunar esse sindicalismo "autêntico", enraizado nas fábricas e que se supunha hábil em negociar salários e melhores condições de trabalho, com um sistema laboral vertebrado pelo fordismo periférico.

E ainda que contra a inclinação de Vidal, a campanha pela reposição dos $34,1 \%$ catalisou a insatisfação operária, impulsionando o ciclo grevista de maio de 1978. O entusiasmo operário com a campanha foi tão grande que impôs à diretoria a criação de uma comissão salarial de mobilização aberta a todos os trabalhadores interessados ${ }^{7}$. Além dos ganhos salariais, o movimento de 1978 serviu para pôr fim a um período de dez anos de intenso controle exercido pela aliança empresarial-militar sobre os operários e seus sindicatos. Certos direitos sociais, como o próprio direito de greve, foram restabelecidos na prática ao longo das jornadas grevistas e a liderança sindical metalúrgica do ABCD acumulou enorme prestígio, alcançando uma inédita projeção nacional. Sem mencionar a decisão da burocracia sindical, sob a pressão de agrupamentos marxistas, em discutir a criação do Partido dos Trabalhadores (PT) e da Central Única dos Trabalhadores (CUT).

7 Ver Paranhos (1999). 
No entanto, a campanha salarial do ano seguinte deparou-se com um patronato determinado a derrotar o movimento. Na realidade, o reajuste tornou-se uma questão menor. As empresas cobravam dos militares o retorno à "normalidade". Após dez dias de greve e temendo a intervenção do Ministério do Trabalho, a burocracia sindical encaminhou uma proposta de retomada do trabalho que foi rechaçada por uma assembleia de 90 mil trabalhadores. Imediatamente o ministério decretou a intervenção em São Bernardo e Santo André.

Mesmo após o fim da greve e sem conquistas imediatas, os "peões" do ABCD deram uma impressionante demonstração de apoio ao sindicato, reunindo, durante as comemorações do $1^{\circ}$ de maio, aproximadamente 150 mil pessoas em São Bernardo. O processo grevista de março mostrou ao patronato e ao regime militar que não seria fácil desmobilizar o ativismo no ABCD. Ao mesmo tempo, a greve de 1979 serviu para elimi156 nar quaisquer dúvidas a respeito do papel desempenhado pelo Estado naqueles conflitos industriais do final dos anos 1970. A imagem de uma aliança empresarial-militar forjada contra os operários foi se consolidando na consciência metalúrgica. No tocante à burocracia sindical, a lição era clara: não seria possível alcançar concessões sem o recurso às greves.

O movimento de 1979 coincidiu com a escolha de João Batista de Oliveira Figueiredo para a Presidência da República e as promessas de "redemocratização" do regime entraram na pauta política nacional. Se até meados dos anos 1970 a burocracia sindical de São Bernardo havia advogado um distanciamento em relação às questões políticas nacionais, o final da década testemunhou uma rápida politização das reivindicações. Além disso, após o malogro da campanha salarial de 1979, e diante de sinais claros de agitação nas bases, à burocracia pouco restava a fazer que não fosse acompanhar o desejo dos trabalhadores de construir a greve geral metalúrgica: 
O sindicato não decretou a greve, mas esta foi decretada por uma assembleia que houve numa segunda-feira. Antes de o pessoal do sindicato falar em greve, um pessoal já estava gritando por greve geral. A ameaça existia, mas ainda se esperava conseguir alguma coisa na mesa-redonda que tinha na mesma segunda-feira. Eu fiquei na primeira noite de greve dentro do sindicato. Às $11 \mathrm{~h} 30$ chega o pessoal da Schuller parado, os caras tinham parado antes da hora marcada. Depois chega o pessoal da Brastemp, chega o pessoal da Villares, todo mundo querendo saber se a greve tinha sido decretada. Foram lá pra saber se a greve tinha sido decretada. Foram lá pra saber mas já tinham parado. Da meia-noite às 6 da manhã foram realizadas quatro assembleias. [...] Então a decisão [...] era não fazer piquete. [...] Mas, na verdade, até aquele momento esses operários não estavam acreditando muito em greve geral. Então eles alegavam: "Olha nós temos que ir pra porta da fábrica, pra não deixar ninguém entrar”. Quem começou o piquete [...] foram os próprios operários que ficaram na porta da fábrica, deram-se os braços e não permitiram a ninguém entrar. [...] Então, eu acho que esse conjunto de coisas é que levou à greve geral (operário metalúrgico, citado em Antunes, 1992, p. 45).

Contando com um pouco mais de liberdade de ação e acumulando experiências de enfrentamento com a aliança empresarial-estatal, a burocracia sindical de São Bernardo percebeu que, naquelas condições, mesmo questões relativas à segurança no ambiente de trabalho transformavam-se rapidamente em ameaças às empresas e, em consequência, ao regime. Tendo isso em vista, a burocracia sindical decidiu abraçar o projeto de construção do PT e passou a fazer duras críticas aos planos de "redemocratização" esboçados pela ditadura. A decisão de criar um novo partido apoiou-se na conclusão de que os operários não podiam depender da tutela estatal. Dispensável dizer que o acentuado 
fortalecimento da onda grevista, que passou de cerca de meio milhão de trabalhadores, em 1978, para mais de 3 milhões, em 1979, pesou de maneira definitiva para a decisão de fundar o PT. Vale observar, ainda, que $17 \%$ do total das greves ocorridas em 1979 concentrou-se na indústria da construção civil, demonstrando que o jovem precariado operário estava de fato na vanguarda da mobilização operária (Coutinho, 1980).

Em 1980, a mobilização operária foi novamente testada. Como no ano anterior, a greve geral operária foi decretada no dia $1^{\circ}$ de abril, logo após o malogro da campanha salarial. Mais uma vez o movimento espalhou-se pelas empresas da região e contou com o suporte de um nível inédito de organização sindical: prevendo a intervenção do Ministério do Trabalho, um comando de greve foi organizado e, em caso de prisão das lideranças, outros militantes sindicais assumiriam as funções dos presos. 158 Além disso, 45 ativistas foram encarregados de transmitir as diretrizes à comissão de salários e mobilização, formada por cerca de quatrocentos trabalhadores distribuídos pelas fábricas e pelos bairros, cujo papel seria estabelecer a ligação entre as bases e o comando. As assembleias gerais eram as principais instâncias e eram convocadas com certa frequência para reavaliar a situação do movimento. Finalmente, o fundo de greve garantia algum respaldo material para os operários.

Ainda assim, os trabalhadores não conseguiram suplantar a determinação da aliança empresarial-militar de não atender nenhuma reivindicação. Seja por questões relativas aos salários, seja por conta das duras condições de trabalho, as greves metalúrgicas questionavam diretamente a política econômica da ditadura. De pronto, o Ministério do Trabalho interveio nos sindicatos, encarcerando e processando os líderes sindicais com base na Lei de Segurança Nacional. Após 41 dias de intenso conflito, o movimento 
grevista, embora apoiado em uma notável unidade entre o operariado profissional e o jovem precariado metalúrgico, foi derrotado. A despeito desse contratempo, a greve logrou desnudar aos olhos dos "peões" a verdadeira natureza da distensão do regime: concessões aos trabalhadores estavam fora de questão.

O movimento grevista do final dos anos 1970 trouxe de volta a questão operária para o centro do palco, ajudando a revelar a natureza reacionária dessa ideologia empresarial. Apoiada no reconhecimento de que o conflito entre o trabalhador e a empresa é permanente, a politização da consciência operária resultou curiosamente do confinamento do conflito trabalhista ao espaço privado do chão de fábrica. Proibidos de se manifestar nas ruas, os metalúrgicos viram-se obrigados a transformar a produção imediata em seu palco de lutas. "Não é possível fazer greve e não é possível não fazer greve": a solução para essa contradição foi "picar" os cartões e cruzar os braços.

Da "explosão de consciência de classe" verificada nesse período adveio a revivificação das assembleias metalúrgicas e das comissões de fábrica, redefinindo os horizontes da mobilização operária no país. Evidentemente, o sentido dessa "explosão" não se limita à "espontaneidade" da revolta operária. Ao contrário, a "súbita" intervenção do precariado metalúrgico e da construção civil no final dos anos 1970 foi antecedida pelo acúmulo de experiências de resistência operária somado à ação clandestina das "oposições sindicais" surgidas no início da década. Enfrentando burocracias pelegas, as oposições apostavam nas comissões de fábrica como meio para criar um novo sindicalismo, independente e representativo.

Vale observar que nosso esforço no presente capítulo procurou se afastar de uma interpretação "metafísica" da explosão de consciência de classe. Ao contrário, buscamos combinar as características mais salientes da regulação 
autoritária e do regime de acumulação despótico a fim de apreender o ciclo grevista como uma construção social enraizada no amadurecimento do classismo prático do precariado metalúrgico do ABCD. Aos nossos olhos, essa "explosão" assentou-se sobre dois pilares: objetivos táticos e estratégicos. Por um lado, temos as reivindicações imediatas ligadas às diferentes campanhas salariais e ao dia a dia das greves. Por outro, a necessidade de potencializar a consciência operária por meio de instrumentos organizativos, tais como um novo partido político ou uma nova central sindical.

Das "operações tartaruga" no início dos anos 1970 aos protestos liderados pelos setores profissionais entre 1973 e 1974, até chegarmos às paralisações de 1977, a "explosão" amadureceu lentamente na consciência do precariado metalúrgico do ABCD. Logo após o lançamento da campanha salarial de 1978, surgem as operações "gato selvagem", 160 em que os operários paralisavam o trabalho e logo retomavam a produção. Além de dificultar a repressão das chefias, essa tática permitia que os operários avaliassem sua força antes de iniciar o movimento grevista. Com a experiência acumulada em 1973 e 1974, os operários concluíram que o melhor momento para deflagrar o movimento era ou após o café ou após o almoço, pois as máquinas já estariam paradas. Assim, enfraqueciam a pressão das chefias, que cairia sobre os primeiros a cruzar os braços.

$\mathrm{O}$ apetite grevista amparou-se na indignação disseminada com salários e condições de trabalho. Por sua vez, a resiliência dos operários apoiou-se na ação política clandestina de grupos organizados dentro e fora das empresas. Dispensável dizer que o trabalho organizativo desses militantes, muitos deles ligados às oposições sindicais e à pastoral operária, foi decisivo tanto para o sucesso do movimento grevista como para o fortalecimento das comissões de fábrica. Além disso, a mobilização operária no chão de 
fábrica criou centenas de comissões para negociar os encaminhamentos da greve com as empresas. O impulso para a criação e a reapropriação dessas comissões provinha, como não poderia deixar de ser, da forte agitação nas bases metalúrgicas, que perceberam nas comissões uma oportunidade ímpar de auto-organização, a um só tempo eficaz como instrumento de resistência ao despotismo fabril e independente do sindicato ${ }^{8}$.

\section{Considerações finais}

Em resumo, diríamos que no final dos anos 1970, um inédito ciclo grevista dirigido por uma burocracia sindical afinada com a inquietação das bases metalúrgicas subverteu a estrutura sindical oficial, ameaçando a estabilidade política da ditadura militar. A decisão do aparelho de Estado de cassar sua liderança não surtiu o efeito esperado, simplesmente porque a força motriz da rebelião não era o sindicato, mas o próprio grupo operário. Num primeiro momento, o sindicato traduziu essa rebelião em uma série de campanhas reivindicativas mais ou menos bem-sucedidas, entrando em conflito com a própria estrutura sindical oficial da qual é produto (Boito Júnior, 1991). No momento do refluxo da rebelião operária, especialmente após a derrota da greve de 1980, a burocracia sindical reassumiu, não sem tensões internas, sua função na estrutura oficial.

Se a hegemonia lulista que vigorou no país entre os anos de 2003 e 2016 foi um modo de regulação que logrou constituir certas margens de consentimento popular por meio da incorporação de parte das reivindicações dos "de

\footnotetext{
${ }^{8}$ Mesmo após a derrota do ciclo grevista, em muitas empresas consideradas estratégicas pelo movimento sindical o processo de mobilização das bases não refluiu. As plantas da Ford e da Scania estavam entre aquelas que sustentavam os mais altos níveis de mobilização e apoio ao sindicato. As duas greves com a ocupação da Ford ocorridas em maio e novembro de 1981 demonstram bem isso: após a demissão de 450 trabalhadores, no dia 3 de julho de 1981, os operários decidiram entrar em greve exigindo a readmissão dos demitidos. Ver Rodrigues (1990).
} 
baixo" em reação à subversividade esporádica dos subalternos, a trajetória do novo sindicalismo pode nos dizer muito sobre as raízes da crise atual. Não se trata apenas da origem do PT. Por si só, isso seria suficientemente importante para justificar um retorno às etnografias e aos estudos de caso que, ao longo dos anos 1970, registraram e analisaram a relação dos "peões" do ABCD com a burocracia sindical de São Bernardo. Antes, porém, a revisita a essas pesquisas permitiu identificar os primeiros passos de uma nova forma de dominação social cujo fundamento localizou-se no encontro de dois tipos distintos, porém complementares, de consentimento.

Por um lado, vimos como a mobilização operária dos anos 1970, alimentada pela insatisfação com os salários e as condições de trabalho e apoiada pela ação clandestina de agrupamentos políticos, detonou o maior ciclo grevista da história do país (Noronha, 2009). Nesse momento, a 162 burocracia sindical de São Bernardo, pressionada pelos operários e incapaz de negociar com a aliança empresarial-militar, subverteu, na prática, a estrutura oficial, dirigindo um ciclo de greves julgadas "ilegais" pelo regime. Entretanto, após a derrota da greve de 1980, essa burocracia reassumiu progressivamente seu lugar na estrutura sindical oficial, sem, contudo, deixar de afiançar concessões aos trabalhadores, mostrando-se igualmente sensível às reivindicações das bases, além de permeável à incorporação daqueles operários que se destacavam pelo trabalho organizativo nas empresas.

A trajetória de Lula da Silva aponta para essa direção: mesmo fazendo parte da diretoria ampliada do sindicato em 1969, aproximou-se da oposição a Paulo Vidal, reconciliando-se com o "pelego" sindical em troca de uma vaga na diretoria efetiva de 1972. Eleito diretor, ele passou a cuidar do recém-criado setor de previdência social e FGTS do sindicato. Escolhido por Vidal para encabeçar 
a chapa situacionista, procurou se cercar de novos ativistas oriundos das principais empresas do ABCD paulista. Surpreendido pela vitalidade da greve de 1978, viu-se obrigado a ampliar a direção sindical criando as comissões de salários e de mobilização. Lula da Silva ergueu um consentimento ativo à sua liderança pela frequente incorporação às fileiras sindicais dos ativistas mais destacados nas empresas ${ }^{9}$. Contou para isso com o decidido apoio de diferentes agrupamentos políticos reorganizados em torno do PT e da CUT.

No encontro entre essas duas formas de consentimento, percebemos como a subversividade inorgânica transformou-se em consentimento ativo para muitas daquelas lideranças provenientes das bases operárias. Além disso, podemos da mesma maneira notar em que medida o poder sindical oficial foi sendo conscientemente restabelecido pela burocracia, em detrimento das assembleias de fábrica. E uma nova forma de dominação social - apoiada sobre a pacificação reformista dos conflitos trabalhistas e somada à integração à estrutura sindical oficial, isto é, ao Estado, daqueles ativistas mais destacados - começa a se insinuar... Uma forma de dominação que desabrochou plenamente apenas após as eleições presidenciais de 2002 e que, aos nossos olhos, foi uma das principais responsáveis pela despolitização das relações sociais promovida pelos governos petistas de Lula da Silva e Dilma Rousseff (Hunter, 2010).

\footnotetext{
9 A trajetória de Vicente Paulo da Silva, o Vicentinho, ajuda-nos a entender esse processo. Filho de trabalhadores rurais sem-terra, Vicentinho migrou para São Paulo após transitar por inúmeras ocupações informais em Acari, no Rio Grande do Norte. Em 1976, logo ao chegar em Diadema, foi contratado pela empresa metalúrgica Tamet como inspetor de qualidade, filiando-se ao Sindicato dos Metalúrgicos de São Bernardo no ano seguinte. Em 1980, trabalhando como inspetor de qualidade na Mercedes-Benz, Vicentinho destacou-se como um dos principais líderes da comissão de mobilização da greve de 1979, elegendo-se, em 1981, vice-presidente do sindicato. Em 1987, ele sucedeu a Jair Meneguelli na presidência do Sindicato dos Metalúrgicos de São Bernardo e Diadema, tornando-se presidente nacional da CUT sete anos depois.
} 


\section{Ruy Braga}

é professor e chefe do Departamento de Sociologia da Universidade de São Paulo (USP).

\section{Bibliografia}

ANTUNES, Ricardo. 1992. A rebeldia do trabalho: o confronto operário no ABC paulista (as greves de 1978-1980). Campinas: Editora Unicamp.

BATALHA, Claudio Henrique de Moraes. 2000. A historiografia da classe operária no Brasil: trajetória e tendências. In: FREITAS, Marcos Cezar de. Historiografia brasileira em perspectiva. São Paulo: Contexto, pp. 32-49. BOITO JÚNIOR, Armando. 1991. Reforma e persistência da estrutura sindical. In: (org.). O sindicalismo brasileiro nos anos 80. São Paulo: Paz e Terra, pp. 26-51.

BRAGA, Ruy. 2012. A política do precariado: do populismo à hegemonia lulista. São Paulo: Boitempo.

BRITO, José Carlos Aguiar. 1989. A tomada da Ford: o nascimento de um sindicato livre. Petrópolis: Vozes.

BURAWOY, Michael. 1985. The politics of production: factory regimes under capitalism and socialism. New York: Verso.

164 COUTINHO, Ronaldo do Livramento. 1980. Operário de construção civil: urbanização, migração e classe operária no Brasil. Rio de Janeiro: Achiamé.

FREDERICO, Celso. 1978. Consciência operária no Brasil. São Paulo: Ensaio.

HUMPHREY, John. 1983. Fazendo o milagre: controle capitalista e luta operária na indústria automobilística brasileira. Petrópolis: Vozes.

HUNTER, Wendy. 2010. The transformation of the workers' party in Brazil, 1989-2009. New York: Cambridge University Press.

LÖWY, Michael. 1962. Consciência de classe e partido revolucionário. Revista Brasiliense, n. 41, pp. 159-160.

LÖWY, Michael; CHUCID, Sara. 1962. Opiniões e atitudes dos líderes sindicais metalúrgicos. Revista Brasileira de Estudos Políticos, n. 13. Não paginado.

MANDEL, Ernest. 1992. Power and money: a marxist theory of bureaucracy. New York: Verso.

MARSON, Adalberto. 1992. Lugar e identidade na historiografia dos movimentos sociais. In: BRESCIANI, Maria Stella et al. Jogos da política: imagens, representações e práticas. São Paulo: Marco Zero, pp. 44-59.

NORONHA, Eduardo. 2009. Ciclo de greves, transição política e estabilização: Brasil, 1978-2007. Lua Nova, n. 76, pp. 119-168. 
PARANHOS, Kátia Rodrigues. 1999. Era uma vez em São Bernardo: o discurso sindical dos metalúrgicos (1971-1982). Campinas: Editora Unicamp. OLIVEIRA, Francisco de; BRAGA, Ruy; RIZEK, Cibele Saliba (orgs.). 2010. Hegemonia às avessas: economia, política e cultura na era da servidão financeira. São Paulo: Boitempo.

RAINHO, Luís Flávio. 1980. Os peões do Grande ABC. Petrópolis: Vozes. RODRIGUES, Iram Jácome. 1990. Comissão de fábrica e trabalhadores na indústria. São Paulo: Cortez. 


\section{TRABALHO E POLÍTICA EM SÃO BERNARDO: ARQUEOLOGIA DE UMA HEGEMONIA PRECÁRIA}

RUY BRAGA

Resumo: O principal objetivo deste artigo é revisitar as etnografias do trabalho operário, assim como os estudos de caso ampliados que, ao longo dos anos 1970 e 1980, registraram a transformação do grupo operário metalúrgico de São Bernardo em um dos mais importantes atores políticos do processo de redemocratização do país, precipitando o fim da ditadura militar e inaugurando o que alguns autores chamaram de "era das invenções democráticas". Para tanto, inicialmente pretende-se enfocar as raízes sociais do processo de inquietação operária no tocante à relação entre o recrudescimento do despotismo fabril e os limites à negociação impostos pela regulação autoritária como catalisador do ciclo grevista que se estendeu entre 1978 e 1981. Finalmente, busca-se identificar no contexto histórico da onda grevista de fins dos anos 1970 a formação da relação social hegemônica que combinou o consentimento passivo das bases sociais com o consentimento ativo das lideranças sindicais na criação da regulação lulista dos conflitos sociais que vigorou no país entre os anos de 2003 e 2016.

Palavras-chave: Sindicalismo; São Bernardo; Lula; Greves; Peões.

\section{WORK AND POLITICS IN SÃO BERNARDO: ARCHEOLOGY OF A PRECARIOUS HEGEMONY}

Abstract: The main objective of the article is to revise the ethnographies of labor, as well as the extended case studies that during the 1970s and 1980s saw the transformation of the São Bernardo metalworking group into one of the most important political actors in the redemocratization process of the country, precipitating the 
end of the Brazilian military dictatorship and inaugurating what some authors called the "era of democratic inventions". For such, it focuses initially on the social roots of the workers' unrest process on the relationship between the upsurge of industrial despotism and the limits to negotiation imposed by authoritarian regulation as a catalyst for the strike cycle that lasted from 1978 to 1981. Finally, this article seeks to identify, within the historical context of the strike wave of the late 1970s, the formation of the hegemonic social relation that combined the passive consent of social bases with the active consent of the union leaders in the creation of Lula's regulation of social conflicts style that prevailed in the country between the years 2003 and 2016.

Keywords: Syndicalism; São Bernardo; Lula; Strikes; Peons.

Recebido: 14/06/2018 Aprovado: 17/07/2018 